\title{
Satwa Negeriku: STEM-based encyclopedia as literacy media for elementary student

\author{
Mukhsin Alfian ${ }^{1}$, Ika Maryani ${ }^{2,}$ * \\ PGSD, Faculty of Teacher Training and Education, Universitas Ahmad Dahlan, Indonesia \\ ${ }^{1}$ mukhsinalfian61@gmail.com, ${ }^{2}$ ika.maryani@pgsd.uad.ac.id * \\ * Corresponding author
}

\begin{tabular}{l}
\hline ARTICLE INFO \\
\hline Article history \\
Selected paper from The $3^{\text {rd }}$ \\
Symposium on Biology Education \\
(Symbion), Yogyakarta-Indonesia, \\
August 31, 2019. Peer-reviewed \\
by Symbion Committee and \\
Editorial Board of Jurnal \\
Bioedukatika
\end{tabular}

Received December 26, 2019

Revised February 5, 2020

Accepted February 20, 2020

Keyword:

Elementary school

Encyclopedia

Literacy

STEM

\begin{abstract}
This research aims to develop, measures the feasibility, and implements STEM-based Encyclopedia to train the literacy of elementary school students. This study uses a 4D development model from Thiagarajan. The subjects were students in grades 4,5 , and 6 of the teachers at Muhammadiyah Pepe Elementary School, Yogyakarta. Encyclopedias were tested on students and teachers after proper approval by material experts, linguists, and media experts. Data obtained through questionnaires, interviews, field notes and observations. The validation results show that the Encyclopedia is worth using to support the literacy program. The results of the small group trial received a value of 95 (very good), the large group trial received a score of 92 (very good), and also the good application received a score of 91.5 (very good). Students find encyclopedias very interesting, easy to understand, and increase students' understanding of endangered species in Indonesia. The observations also show the use of STEMbased encyclopedias leading to the realization of competency literacy indicators. The teacher also appreciates that the encyclopedia is suitable to be used as teaching material that supports the literacy program.
\end{abstract}

This is an open access article under the CC-BY-SA license.

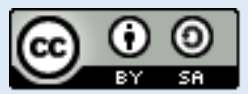

\section{Introduction}

The rapid development of times, science, and technology these days has influenced every part of human life, particularly in the world of education. It should always change along with the times. Technological progress increasingly leads students to be able to develop in accordance with their era (Salleh, Jusoh, Embong, \& Mamat, 2018). Challenges that must be faced by the students in order to survive in this era of changes are very complex. Student must have problem solving skill, communication, innovation, and must possess high creativity (Carmeli, Gelbard, \& Reiter-Palmon, 2013; Siswono, 2011). One of the fundamental skills that student must have to reach those competencies are literacy.

Literacy has important role in supporting the student success in study. Literacy really depends on the availability of learning material. Literacy in learning can train student's comprehension of a problem, so that, it supports the achievement of logical thinking skills, critical, creative, and able to correct argumentation and can collaborate (Pertiwi, Atanti, \& Ismawati, 2018). However, the 
implementation of literacy activity in the school still encounters many issues. The availability of learning source is still limited in aspect of amount, type, and the quality (Gottesman \& Hoskins, 2013; Imer, 2016). Reading material currently available is not much choice and is limited to certain topics. The data was obtained from preliminary studies in some schools in Yogyakarta. Observation conducted in SD Muhammadiyah Pepe, SD Negeri Kotagede 4, and SD Muhammadiyah Bodon in early 2019 showed data that reading materials were really limited and had not fulfilled all the students' requirement yet, school had not provided learning source yet that can enhance students reading interest. This problem has an impact on the less optimal culture of student literacy in many schools in Indonesia.

Regarding to these issues, Ministry of Education and Culture states that 21st century learning emphasizes on student's ability to search information from various sources, to formulate problem, to think analytical and cooperate as well as to collaborate in problem solving (Sipayung, Sani, \& Bunawan, 2018). Therefore, it needs an appropriate learning approach that can lead to the ability of these students. Learning approach that allows students to have ability to solve problems by utilizing information as a source of learning, formulating problems, analytical thinking and cooperation also collaborating in solving problems one of which is the STEM Approach (Science, Technology, Engineering, and Mathematics) (Acar, Tertemiz, \& Taşdemir, 2018; Gottesman \& Hoskins, 2013; Tipani, Toto, \& Yulisma, 2019).

STEM aims to form innovative generation that can solve the problem using science and technological approach (Corlu, Capraro, \& Capraro, 2014). Through STEM approach, students are invited to think comprehensively using problem solving pattern that is based on five aspects of STEM. STEM can teach students to think critically and own techniques and designs to solve real-world problems based on scientific approaches in STEM aspects (Wijaya, Karmila, \& Amalia, 2015). Therefore, STEM integration in learning process includes learning materials have a great potential in forming the students to become problem solver.

In STEM learning process, information is formed through decision making collaboratively and creatively, which means students give all their skills in learning process, science, knowledge, technology, engineering, and mathematic, so it can solve a problem (Wijaya et al., 2015). One of the STEM-based learning processes is there is an activity using information. The activity using information is one of the competencies in literacy (Setiawan, 2017). Literacy component made is based on the idea to integrate all STEM disciplines in bridging student to gain knowledge into wider context (Moore \& Tank, 2014). Based on the problems, STEM is considered important in developing literacy, thus its affect to the students' competency can be felt directly.

Literacy reading material integrated with STEM can be used in literacy activity implementation of elementary students. Literature sources that contain basic information about things that can encourage literacy are certainly very necessary. One of the learning sources that can be developed to fulfill the need is STEMbased encyclopedia. The encyclopedia is a collection of references with basic and complete information in science (Maryono, Ishartati, Bektiningsih, \& Supriyono, 2017). Encyclopedia is one of the examples of learning material that also can turn into reference material of students' literacy activity to improve their knowledge. STEMbased encyclopedia integrates science, reading, technology/digital and mathematic literacy activity as media in presenting a problem, in order the reader can explore and analyze solution to solve the problem.

The discussion raised in this encyclopedia is related to the problem of the increasing cases of animal exploitation in Indonesia. Based on the information cited from (Profauna Indonesia, 2018), it is estimated that there are 300.000 types of wildlife in the world, which is $17 \%$ of them exist in Indonesia. Indonesia is as the top rank of countries that has mammal diversities with 515 types. And Indonesia is also a home for more than 1.539 types of birds, as well as habitat for $45 \%$ fishes in the world. The main reason of these animals' extinction is influenced by the decrement of forest as their main habitat. The forests are exploited and turned into plantation and other industrial activities.

Through this research, the writer wants to develop Satwa Negeriku Encyclopedia as a literacy material which the feasibility is measured, so that it can be interested and 
applied to the literacy activities of elementary school students. The encyclopedia material focuses on introducing various types of endangered wildlife in Indonesia. The advantages of STEM-based encyclopedia, such as being an enrichment learning source that contains information about endangered animal in Indonesia, distribution, breeding, unique facts, extinction cases, and also its conservation effort. The STEM approach used is using instill model where science has the biggest proportion, while technology, engineering, and mathematic aspects are instill inside. The scientific aspect examines information about my country's animals from a scientific point of view. Technological aspect can be seen in barcode connected to youtube.com that directs reader to the related supporting material videos. Engineering aspect can be seen from infographic about each animal. While mathematic aspect is shown by statistic distribution data or animal growth in Indonesia and in the world. This is expected can train reading, science, numeric, or technology literacy of the students. Final objective is after reading the encyclopedia students have awareness in recognizing environmental problems and maintaining the survival of endangered species in Indonesia.

\section{Method}

\section{Research Procedure}

The research and development use 4D (four-D) model developed by Thiagarajan. The stage of the research is define, design, develop, and disseminate (Washington, 1974) (see Table 1).

Table 1. 4D Stages in developing encyclopedia

\begin{tabular}{cl}
\hline \multicolumn{1}{c}{ Stage } & \multicolumn{1}{c}{ Description } \\
\hline & Requirement Analysis: students' literacy is still low, lack of adequate reading material \\
& literacy. \\
& Selecting Product: encyclopedia (reason: requires learning source enrichment) \\
Define & Selecting approach: STEM (reason: is adjusted by characteristic literacy and STEM) \\
& Material analysis: wildlife distribution in Indonesia (reason: very close with the students' \\
& world) \\
& Pupil analysis: having high curiosity, reading interest, it needs to be developed with \\
& interesting learning source. \\
& Encyclopedia dimension: A4 size to make it more comfortable to read by elementary \\
& school students. \\
& Content: 3 fauna (Asiatic, transition, Australist) which each of them consist of 5 animals \\
& that will be described from the aspect of animal, morphology, habitat, food, breeding, \\
& population, threat, observation effort, and unique facts that is presented in segment \\
& "Did you know?" \\
& STEM aspect: Science (science-based description), technology barcode link video that can \\
Design & diaccessed via android, or IOS, engineering (infographic), and mathematic (table and \\
& Readability test, expert validation, user assessment \\
Revision in every stage & \\
Dissemination through learning process in school cooperates with publisher for \\
disseminating to the market.
\end{tabular}

\section{Product Trial}

First trial conducted was readability test by researcher and elementary school students. Later was expert's validation test conducted by material expert, media expert, and language expert. This stage was conducted in order to receive critics, suggestion, and improvement input of the product. Revision was carried out based on an input from the experts. After the encyclopedia stated feasible, then it was tested to the students and teachers.

On development stage, Satwa Negeriku Encyclopedia was validated and on trial. Validation stage was carried out to know the feasibility/validity of Satwa Negeriku
Encyclopedia from various aspects before it was on trial. The aspects are material, media, and language. Data collection instrument on validation stage was using closed questionnaire with Likert 1-4 scale, the category are as follows Table 2.

Table 2. Questionnaire rating rubric validator

\begin{tabular}{lll}
\hline \multicolumn{1}{c}{ Rating } & \multicolumn{1}{c}{ Criteria } \\
\hline 4 & Strongly Agree & \\
3 & Agree & \\
2 & Less Agree & \\
1 & Not Agree & (Sugiyono, 2017)
\end{tabular}

Every rating sheet is analyzed to determine the score percentage feasibility 
of every validator based on categorization from Arikunto and Safruddin A.J (2009) (see Table 3) as follows:

Information:

$$
P=\frac{\sum x i}{\sum \mathrm{xj}} X 100
$$

$\mathrm{P} \quad=$ Percentage Feasibility

$\Sigma x i=$ Score rating answer amount from validator

$\Sigma x j \quad=$ Highest instrument score number

Table 3. Validator questionnaire result criteria

\begin{tabular}{ll}
\hline \multicolumn{1}{c}{ Achievement Level } & \multicolumn{1}{c}{ Qualification } \\
\hline $81-100$ & Very Good \\
$61-80$ & Good \\
$41-60$ & Quite Good \\
$21-40$ & Less Good \\
$<20$ & Not Good \\
\hline
\end{tabular}

Trail to the students and teachers were conducted in high grade students of SD Muhammadiyah Pepe in July 2019. Product trial was aimed to find the impact of using Satwa Negeriku Encyclopedia toward literacy activity of the students. Trial was carried out in three stages, which are on small scale stage, bigger scale stage, and implementation stage.

Data collection instrument of both trials was using closed questionnaire. Students' respond questionnaire rating was using Guttman's scale, which is Yes or No. The Guttman scale was chosen to avoid the level of student hesitation in determining the score and the answers given more clearly, decisively and accurately. Student who answered YES will get score I and who answered NO will get score 0 . The score was analyzed to determine rating category of every criteria based on similarity and categorization from Sudjana (2017) Table 4 as follows:

Annotation:

$$
K=\frac{F}{\mathrm{~N}} X 100
$$

$\mathrm{K}=$ The criteria value category sought

$\mathrm{F}=$ Number of criteria answered YES

$\mathrm{N}=$ Total Students

Table 4. Student's questionnaire rating criteria

\begin{tabular}{ll}
\hline \multicolumn{1}{c}{ Rating } & \multicolumn{1}{c}{ Criteria } \\
\hline $0-20$ & Strongly Disagree \\
$21-40$ & Disagree \\
$41-60$ & Quite Agree \\
$61-80$ & Agree \\
$81-100$ & Strongly Agree \\
\hline
\end{tabular}

\section{Research Subject}

Trial subjects in this research were students in high grade of SD Muhammadiyah Pepe. The subjects were tried on a small-scale stage involving 5 students, and ended at the implementation stage with respondents as many as all students in the high class (class 4,5 , and 6 ) in SD Muhammadiyah Pepe. The selection of students who are tested is done by random method. Besides to the students, trial was also conducted toward 3 classroom teachers to find respond and their rating toward encyclopedia and its feasibility as literacy reading material.

\section{Type of Research Data}

This research was using qualitative and quantitative data. Qualitative data comes from open questionnaire, observation, and unstructured interview. While quantitative data is derived from validation questionnaire sheet and students closed questionnaire sheet.

\section{Results and Discussion}

\section{Define}

Based on initial study and requirement analysis, STEM-based encyclopedia is entitled by Satwa Negeriku, so that, it can describe the overall contents, but still easily to remember and interesting. This encyclopedia consists of three main chapters which are Asiatic Animal, Transition Animal, and Australist Animal, which each of them explains five animals with following description:

a. Asiatic Animal: Sumatran Tiger, Honey Bear, Sumatran Elephant, Javanese Rhino, and Orang Utan.

b. Transition Animal: Hog deer, Maleo Bird, Komodo, and Balinese Starling

c. Australist Animal: Birds of Paradise, Kuskus Bear, Cockatoo, Saw Sharks, and Wallaby.

Encyclopedia creation and development start with gathering the data and news related with 15 endangered animals in Indonesia. For the data and news contain about morphology, habitat, ways in breeding, population threat, until efforts in conserve these endangered animals. The data and news were derived from various sources, such as: book, journal, news portal in network or various internet sites of endangered animal conservation organization both in domestic and abroad.

Beside materials, Satwa Negeriku Encyclopedia is also completed with several features. The features such as Image, QR code contains internet address link, and diagram data presented with colorful background that is comfortable in the eyes. 
STEM integration in Encyclopedia is seen by the content presented inside it. Explanation of each STEM components in Satwa Negeriku Encyclopedia are: Science, the encyclopedia main material trains students' science literacy by discussing survival issues of endangered animals in Indonesia. Technology, there are QR code as the introduction to the technology literacy and bridge students to know the endangered animals further on the internet. Moreover, it can become an introduction media to train students in utilizing learning technology and obtain information. Engineering, infographic and QR code feature trains engineering literacy and graphic design, in the part of effort in conserving or rescuing endangered animal from extinction and also gives experience and information to the students about engineering in animal conservation. Mathematics, statistic diagram shows current data of endangered animal population amount, or percentage of a habit/behavior of certain animal.

\section{Design}

STEM-based Encyclopedia of Satwa Negeriku is designed in A4 size. Besides making the book not too thick, A4 size is selected in order the content in the book can be seen clearly, so that it would be interesting to the students. In the cover page uses 230gram ivory paper with doff finishing. As for the book content, it is used 80 gram. The book is binding by bending.

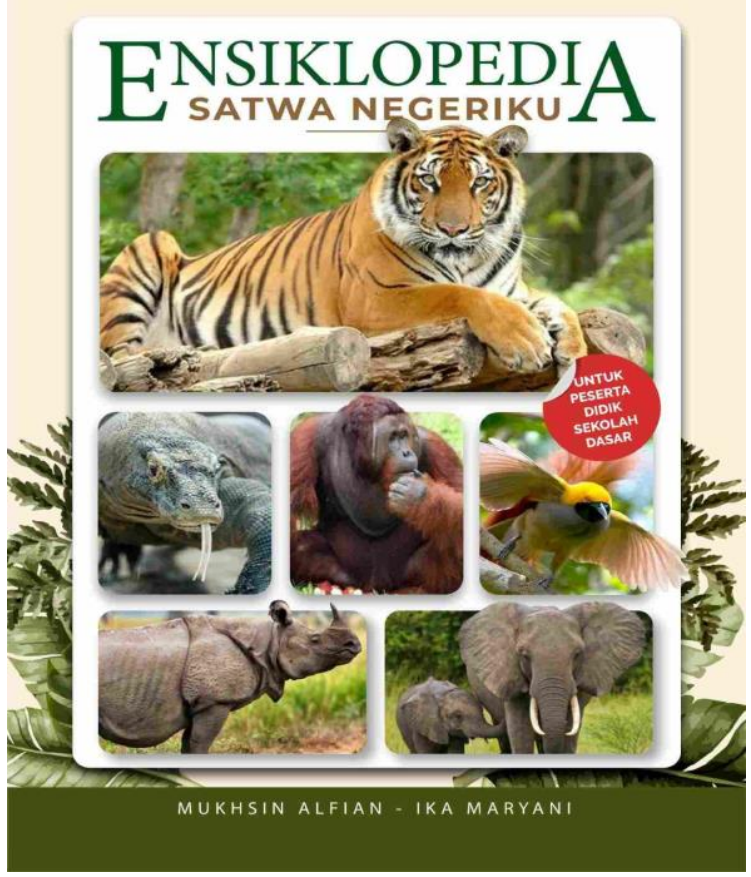

Figure 1.Front cover
Front cover design presents endangered animals that are reflection of the book content. On the above cover part, there is a title "SATWA NEGERIKU ENCYCLOPEDIA" and below it, there are researchers' names, which are Mukhsin Alfian and Ika Maryani. On the rear cover there is the title of the book at the top and the book resume. The encyclopedia cover design can be seen in Figure 1. Front and rear cover design are really reflect the encyclopedia content and STEM approach also integrated inside.

Content of the encyclopedia consists of some components (Figure 2), which are: 1) Book identity page explains book identity, such as book title, writer, designer, and layout designer of the book. 2) Introduction page contains writer's introduction about purpose and expectation for Satwa Negeriku Encyclopedia. 3) Content page contains list of contents from Satwa Negeriku Encyclopedia that can help user to find the desired page in the book. 4) Using QR code instruction page contains instruction using QR code in the book with the help of a smartphone. 5) Material page contains 15 endangered animal materials cover general condition, morphology, habitat, food, behavior, breed, population, and threat, as well as conservation effort. 6) Glossary page contains list of word/foreign term needed to be explained further. 7) Bibliography contains of bibliography and data source of the encyclopedia. 8) Writers identity contains short description of the writers' identity.

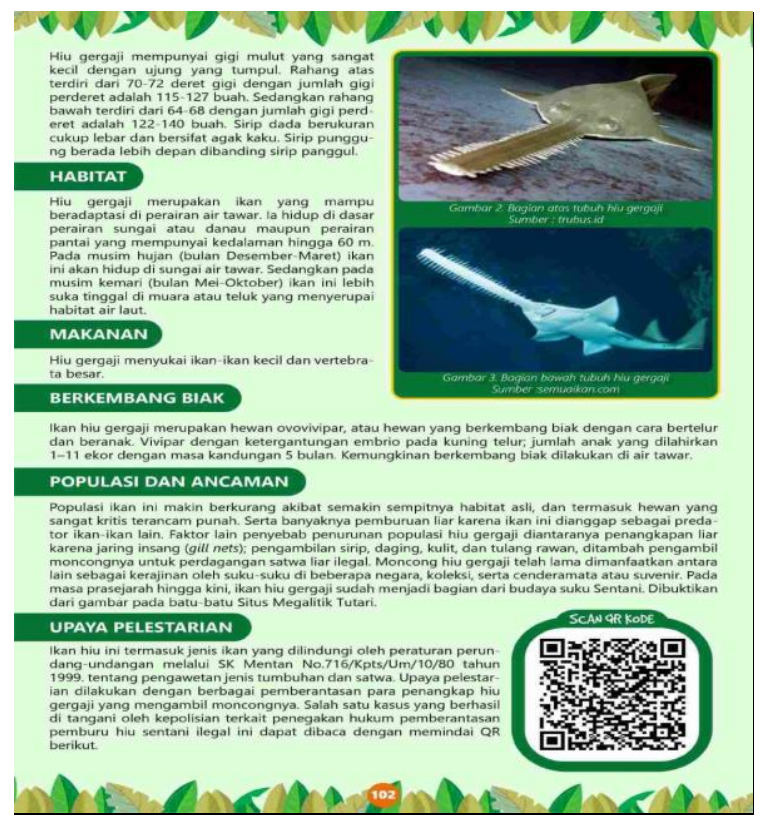

Figure 2.Book content example of Satwa Negeriku encyclopedia. 
Material content presented in Figure 2 is material example on breed aspect, behavior, threat, and population as well as animal image discussed and data diagram number of populations from year to year as an introduction to mathematical literacy, and also barcode that is connected to video of the animals.

The design of the encyclopedia content was made using various colors that is comfortable in the eye resulting easy to be read. Image used in this encyclopedia is maximized with the best resolution, so that it would not blur and unclear.

\section{Develop \\ Material Validation Finding}

Rating on material validation stage uses quantitative data; there are 17 rating aspects in closed questionnaire material validation that covers material presentation, STEM, endangered animal presentation in Indonesia, and reading content literacy aspect. From rating result, it is obtained overall score as 83.8 (Very Good).

Validator asses conformity STEM-based Encyclopedia of Satwa Negeriku as literacy reading material for elementary school students is based on thorough material presentation scope, starting from introducing animal until problems faced by animals in their survival. Material is also presented from concrete to abstract, according to student's intelligence level from concrete instances in nature to abstract things in nature. Moreover, material is also completed with fact and data that is easy to be understood by high grade of elementary school students; it is equipped with relevant examples, so that it enriches students' knowledge.

Besides giving assessment in qualitative data, validator also gives input that material presented is feasible and good without revision, so it can be used for the next stage.

\section{Language validation finding}

Language validation stage rating also uses qualitative data. There are 10 rating aspects on closed questionnaire language validation that covers conformity aspect in using grammar and sentence for high grade of elementary school students, clarity of the source, foreign term/word usage, conformity with Indonesian Language General Guidelines Spelling (PUEBI), and also encyclopedia feasibility as literacy reading material. Based on the rating finding, it was obtained overall score as 90 (very good). Besides giving quantitative data rating, language expert validator also gives input and suggestion if there are some typos, punctuation, and the need of improvement in using PUEBI. On the content part and introduction, it was still needed page number. Thus, validator gives assessment that Satwa Negeriku Encyclopedia overall is feasible to use, however it needs revision/improvement such as writing mistake "menembuh" into "menembus", and lack of noting data sources. Improvements is needed because a reading book for students should be communicative and simple by considering grammar, spelling accuracy, and foreign word usage (Sholahuddin, 2011).

\section{Media validation finding}

The rating uses quantitative data. There are 10 rating aspects on validation questionnaire that cover completeness aspect and conformity in size and book content, image visualization, and color blending, conformity in typography, and its feasibility as students' literacy reading material. Validator also conducts two times rating which is in $3^{\text {rd }}$ July 2019 and $12^{\text {th }}$ July 2019.

On rating conducted by media validator in 31 Juli 2019, it is gained overall score which is 62.5 (good). However, validator found 20 images with low resolution that makes it blur and unclear cause it less interesting. Validator also finds I (one) image that was not corresponding to the description. Thus, validator gave suggestion that Satwa Negeriku Encyclopedia is not feasible yet and it should be revised.

After finishing process, on 12 July 2019, media validator expert carried out rerating process using the same questionnaire. The rating on this date had obtained score of 97.5 (very good). Validator also rated after revision process that Satwa Negeriku Encyclopedia had better changes, so that it is considered to be appropriate and suitable for testing in the next stage.

\section{Trial Finding on Student}

Trail stage on student aimed to find their respond toward Satwa Negeriku Encyclopedia as literacy activity reading material. Trail stage was conducted in 2 times, which is on small scale conducted to 8 (eight) students and bigger scale conducted to 15 (fifteen) students.

\section{Trial Finding on Small Scale}

Small scale trial was conducted to 8 students in 6A class of SD Muhammadiyah Pepe on 15 July 2019. Rating toward Satwa Negeriku encyclopedia was conducted with 
several steps; those are students were given direction and explanation about encyclopedia. Later, encyclopedia was given to the students to be read and used in literacy activity. During literacy activity, students gathered and read encyclopedia together and there were also students who watched $\mathrm{QR}$ code. Students seemed enthusiast and very happy when using encyclopedia in literacy activity. After literacy activity finished, students were given data collection instrument in a questionnaire.

Based on small scare trial by 8 (eight) students, it showed that students rated encyclopedia as a very good literacy media with 95 score from 100 scale. Besides giving quantitative rating, students also gave their comments regarding to Satwa Negeriku encyclopedia. One of the students rated that Satwa Negeriku Encyclopedia was good in the picture, color, and understandable language. Moreover, encyclopedia also can help them to know further on endangered animals such as the features, habitat, and the way to preserve it.

\section{Trial Finding on Bigger Scale}

Bigger scale trial was conducted to random sample, which are 15 students in class 5A, 5B, 6A, and 6B of SD Muhammadiyah Pepe in 16 July 2019. After debriefing, students were called and invited along their friends to read encyclopedia together. During literacy activity, students gathered and read encyclopedia together. Students were enthusiast reading the book. Students were really entertained with the images and demo on using QR. Students also discussed with their friends on the threat faced by the endangered animals. After literacy activity finished, students were given questionnaire rating instrument.

Based on bigger scale trial rating by 15 (fifteen) students toward Satwa Negeriku Encyclopedia, it shows that students respond is on 92 score average (very good). Qualitative respond given by the students states that Satwa Negeriku Encyclopedia is good in clear image and varied, understandable language, and also there are $\mathrm{QR}$ codes that give interesting experience for them in utilizing various learning source.

\section{Disseminate}

In this stage, encyclopedia that has been developed will be distributed to the other students in other class. The aim is to find students' respond about feasibility in using encyclopedia in literacy activity at the wider scale. Besides open questionnaire and interview to the students, teachers' respond are also needed to strengthen worthiness of encyclopedia in using literacy media.

This stage is conducted on 45 students from class 4A, 5C, and $6 \mathrm{~B}$ of $\mathrm{SD}$ Muhammadiyah Pepe in 16 July 2019. After debriefing, students read encyclopedia together with their friends. During literacy activity, students gathered to read encyclopedia together with their friends. The students were enthusiast and really entertained with encyclopedia content. In this stage, discussion process is more visible. There was discussion on threating the animal extinction, also students asked each other about animal behavior that is weird for them, such as the wallowing behavior of hog deer. On the implementation stage, students' rating generates 91.5 score (very good). In this stage, some students expressed that encyclopedia had good picture quality, interesting animal, bright and clear color. Moreover, through this encyclopedia students can recognize endangered animals in Indonesia that are about to be extinct. Through encyclopedia, students can know how the habitat is and what kinds of efforts that can be done to preserve animal survival.

\section{Teacher's Rating}

Rating result from teachers in 4A of SD Muhammadiyah Pepe states that material presented in this encyclopedia has positive content and appropriate with elementary school student's literacy activity. Teacher also rates that material on endangered animal presented in this encyclopedia can add students' knowledge about how to preserve the endangered animals. Besides a lot of complex information that have not widely known yet by students through concrete picture and data presented in table also enrich with many colors, this encyclopedia can draw reading interest of the students, there are material presented in video that is accessed through internet and unique fact of the endangered animal that can add students' knowledge, so it makes easy to remember, to comprehend, and imagine.

Rating by the teachers of $5 \mathrm{C}$ class states that material presented in this encyclopedia has positive content and appropriate with literacy activity objective. Through complete, detailed, and complex material, it encourages students to think critically and emerges curiosity. This can foster students' 
creativity and imagination in telling about endangered animals. Moreover, according to the teachers, material contained in this encyclopedia can be used as reference to support learning material, because there are some learning themes related with environment around the students and preservation effort of endangered animals. Teacher also explains that this encyclopedia does not only enrich the students' knowledge about endangered animals, but also with the existence of STEM aspect inside, it can train the students with various literacy experiences. Encyclopedia arranged with STEM approach has high potential in fostering curiosity and reading interest, so that, it can bring significant impact toward students' comprehension and understanding concept in Natural Science learning (Maryani, Fitriani, \& Sulisworo, 2019).

Other rating given by teachers in $6 \mathrm{~A}$ and $6 \mathrm{~B}$ class describe that the complete encyclopedia material also can develop critical and creative thinking skill of the students. Content and innovation existed in this encyclopedia is also appropriate with students' characteristic. Materials presented in this encyclopedia are considered as complex and able to support thematic learning activity that can introduce endangered animal more detail toward the students. Besides it can stimulate curiosity, the encyclopedia is also able to be used as thematic learning material.

Besides it stated feasible by validators, the teachers also rate that Satwa Negeriku Encyclopedia is feasible, not just as reading material, but also as learning activity for elementary students. Trail on students also shows that Satwa Negeriku encyclopedia is regarded as interesting and able to help students in deriving additional knowledge and encourages students' reading interest. Interesting information in encyclopedia is regarded as something new, as the result, it triggers curiosity. Curiosity is an important aspect in supporting someone's learning interest (Fauziah, Supraptono, \& Kartono, 2018). Reading interest becomes primary requirement in the development of literacy culture.

In the class observation activity, students show activity that conforms to literacy activity implementation in development stage. In that activity, students read encyclopedia material content carefully, read with friends, even discussing with their friends about material contained in the encyclopedia.

Even though STEM in this encyclopedia is only used as approach in book material display not as strategy in learning implementation, displaying STEM-based content also influences knowledge and learning experience obtained by the students. STEM integrated in learning particularly media / learning material is able to increase students' logical thinking because the issues inside connect students with cyber world (Hudha et al., 2019). Studying becomes more meaningful because object studied is very close with students' daily life. This encyclopedia can facilitate students to obtain richer information. Not just by reading literacy activity, but also mathematic literacy that invites students to analyze the table or graphic data related with population amount or percentage of certain endangered animal activity. STEM is very effective in improving science literacy (Ismail, Permanasari, \& Setiawan, 2016).

STEM approach in this encyclopedia can train students' creative abilities in relating four appropriate sciences, so that, students have thorough knowledge and able to improve their creativity (Herak \& Lamanepa, 2019). Moreover, with the existence of literacy technology, the most favored to the students is in the part that students can direct interaction by $\mathrm{QR}$ code feature in order to access video on internet related with endangered animals they are studying. This adds up special attraction for students, and develops their interest to create literacy activity. It shows that literacy indicator achievement through Satwa Negeriku Encyclopedia is success.

\section{Conclusion}

The research process and development has created STEM-based Encyclopedia of Satwa Negeriku that is feasible to be used for elementary school students' literacy material. Validation test result from the experts, trial on students, and teachers' rating show that encyclopedia is very feasible to be used for higher class of elementary school students because it can increase reading interest, develop curiosity, creativity, and logical thinking skills. STEMbased encyclopedia is able to train reading, technology, mathematic literacy of the students through literacy activity conducted in the school. On the next 
research, it is expected that the product can be implemented to the other schools, and also can be studied more on how far its affectivity toward study outcomes or other learning achievements.

\section{Acknowledgement}

We would like to thanks Universitas Ahmad Dahlan for facilitate its research. Then we thank for the students and teachers of Muhammadiyah Pepe Elementary School, Yogyakarta for allowing us to carry out the research.

\section{References}

Acar, D., Tertemiz, N., \& Taşdemir, A. (2018). The effects of STEM training on the academic achievement of 4th graders in science and mathematics and their views on STEM training teachers. International Electronic Journal of Elementary Education, 10(4), 505-513. https://doi.org/10. 26822/iejee.2018438141

Arikunto, S., \& Safruddin A.J, C. (2009). Evaluasi program pendidikan. Jakarta: Bumi Aksara.

Carmeli, A., Gelbard, R., \& Reiter-Palmon, R. (2013). Leadership, creative problem-solving capacity, and creative performance: The Importance of knowledge sharing. Human Resource Management, 52(1), 95-121. https://doi.org/10. 1002/hrm.21514

Corlu, M. S., Capraro, R. M., \& Capraro, M. M. (2014). Introducing STEM education: Implications for educating our teachers for the age of innovation. Education and Science, 39(171), 7485. Retrieved from http://hdl. handle.net/11693/13203

Fauziah, D. A., Supraptono, E., \& Kartono, R. (2018). Pengembangan ensiklopedi digital tari daerah Jawa Tengah berbasis android dengan metode linear sequential model. JURNAL IPTEKKOM: Jurnal Ilmu Pengetahuan \& Teknologi Informasi, 20(1), 77-91. https://doi.org/10. 33164/iptekkom.20.1.2018.77-91

Gottesman, A. J., \& Hoskins, S. G. (2013). CREATE Cornerstone: Introduction to scientific thinking, a new course for STEM-interested freshmen, demystifies scientific thinking through analysis of scientific literature. $\quad C B E$ Life Sciences Education, $\quad 12(1), \quad 59-72$. https://doi.org/10.1187/cbe.12-110201

Herak, R., \& Lamanepa, G. H. (2019). Meningkatkan kreatifitas siswa melalui STEM dalam pembelajaran IPA. EduMatSains: Jurnal Pendidikan, Matematika Dan Sains, 4(1), 89-98. Retrieved from http://ejournal.uki.ac.id/index.php/ edumatsains/article/view/1047

Hudha, M. N., Triwahyuningtyas, D., Rafikayati, A., Fajaruddin, S., Maryani, I., Widiaty, I., ... Permanasari, A. (2019). How is STEM learning for children with special needs in Indonesia? Journal of Physics: Conference Series, 1402(4). https://doi.org/10.1088/17426596/1402/4/044104

Imer, N. (2016). Effects of a teacher professional development program on science teachers' views about using computers in teaching and learning. International Journal of Environmental and Science Education, 11(15), 8026-8039.

Ismail, I., Permanasari, A., \& Setiawan, W. (2016). Efektivitas virtual lab berbasis STEM dalam meningkatkan literasi sains siswa dengan perbedaan gender. Jurnal Inovasi Pendidikan IPA, 2(2), 190. https://doi.org/10.21831/jipi.v2i2.8 570

Maryani, I., Fitriani, I. N., \& Sulisworo, D. (2019). The science encyclopedia based on characters to improve the natural science concepts understanding in elementary school students. Journal of Physics: Conference Series, 1318(1). https://doi.org/10.1088/17426596/1318/1/012016

Maryono, M., Ishartati, I., Bektiningsih, P., \& Supriyono, S. (2017). Ensiklopedi: Koleksi rujukan dengan informasi mendasar dan lengkap soal ilmu pengetahuan. Retrieved from http://masyono.staff.ugm.ac.id/file s/2017/10/Ensiklopedia-ok-.pdf

Moore, T. J., \& Tank, K. M. (2014). Natureinspired design: A picture STEM curriculum for elementary STEM. In Annual Meeting of the Association of 
Science Teacher Educators. Retrieved from http://picturestem.org/wpcontent/uploads/2014/12/ASTE2014-PictureSTEM-Paper.pdf

Pertiwi, U. D., Atanti, R. D., \& Ismawati, R. (2018). Pentingnya literasi sains pada pembelajaran IPA SMP abad 21. Indonesian Journal of Natural Science Education (IJNSE), 1(1), 2429. https://doi.org/10.31002/nse. v1i1.173

Profauna Indonesia. (2018). Fakta tentang Satwa Liar Indonesia | PROFAUNA.

Salleh, M., Jusoh, A., Embong, R., \& Mamat, M. (2018). Learning Organizational Model in the 21th century classroom at Sultan Mahmud science secondary school in Terengganu, Malaysia. International Journal of Academic Research in Progressive Education and Development, 7(4), 410-426. Retrieved from http://hrmars.com/ index.php/papers/detail/IJARPED/5 334

Setiawan, V. (2017). Strategi komunikasi pustakawan dalam implementasi literasi informasi (studi kasus di perguruan tinggi dengan menggunakan dan memanfaatkan eresources). Jurnal Penelitian Komunikasi Dan Opini Publik, 21(1), 15-29. Retrieved from https://jurnal.kominfo.go.id/index. $\mathrm{php} / \mathrm{jpkop} /$ article/download/948/5 97

Sholahuddin, A. (2011). Pengembangan buku ajar kimia kelas $\mathrm{x}$ berbasis reduksi didaktik: Uji kelayakan di SMA Negeri Kota Banjarmasin. Jurnal Pendidikan Dan Kebudayaan, 17(2), $\quad 166 . \quad$ https://doi.org/10. 24832/jpnk.v17i2.15

Sipayung, H. D., Sani, R. A., \& Bunawan, W. (2018, December). Collaborative Inquiry For 4C Skills. 440-445. https://doi.org/10.2991/aisteel18.2018 .95

Siswono, T. Y. E. (2011). Level of student's creative thinking in classroom mathematics. Educational Research and Reviews, 6(7), 548-553.

Sudjana, N. (2017). Penilaian hasil proses belajar mengajar. Bandung: Rosda Karya.

Sugiyono. (2017). Metode penelitian pendidikan: Pendekatan kualitatif, kuantitatif, dan $R \& D$. Bandung: Penerbit Alfabeta.

Tipani, A., Toto, T., \& Yulisma, L. (2019). Implementasi model PjBL berbasis STEM untuk meningkatkan penguasaan konsep dan kemampuan berpikir analitis siswa. BIO EDUCATIO: (The Journal of Science and Biology Education), 4(2), 70-76. Retrieved from http://www.jurnal.unma.ac.id/index .php/BE/article/view/1700

Washington. (1974). Thiagarajan, Sivasailam; And Others Instructional Development for Training Teachers of Exceptional Children: A Sourcebook. Indiana Univ., Bloomington. Center for Innovation in Teaching the Handicapped. National Center for Improvement of Educational System. Council for Exceptional Children, 1920 Association Drive, Reston, Virginia 22091 (Single Copy, \$5.50).

Wijaya, D. A., Karmila, N., \& Amalia, M. R. (2015). Implementasi pembelajaran berbasis STEAM (Science, Technology, Engineering, Art, Mathematics) pada kurikulum indonesia. Proseding Seminar Nasional Fisika Dan Aplikasinya. Retrieved from http://portal.phys. unpad.ac.id/senfa2015/proseding/F P-09_Agusta_Danang.pdf 